\title{
Cave use by the Broad-footed Climbing Rat Rhipidomys latimanus (Rodentia: Cricetidae) in Santander, Colombia.
}

\author{
Miguel E. Rodríguez-Posada
}

Fundación Reserva Natural La Palmita, Centro de Investigación, Grupo de Investigaciones Territoriales para el Uso y Conservación de la Biodiversidad - Bogotá, Colombia. Email: migrodriguezp@yahoo.com

\begin{abstract}
In this note, I report two field observations of $R$. latimanus using caves. These records provide new data about the natural history of $R$. latimanus, previously, this species was considered mainly arboreal and solitary.

Key words: Subterranean ecosystems, Sigmodontinae, Small mammals
\end{abstract}

\section{Resumen}

En esta nota reporto dos observaciones de campo de R. latimanus usando cuevas. Estos registros proveen nuevos datos sobre la historia natural de $R$. latimanus, previamente, esta especie era considerada principalmente arborícola y solitaria. Palabras clave: Ecosistemas subterráneos, Pequeños mamíferos, Sigmodontinae.

Rhipidomys latimanus (Tomes, 1860) is known as an arboreal, nocturnal and solitaire rat (Eisenberg 1989, Linares 1998, Gómez-Laverde et al. 2016). This species is a medium-sized rat (head and body length: $98-124 \mathrm{~mm}$ ), with a haired tail a conspicuous terminal tuff (Tail length: 135-184 mm), and longer than the length of the head and the body (120-150\%). The hindfeet are broad and short with recurved claws (Tribe 2015, Brito et al. 2017). Its geographical distribution comprises easternmost Panama, southward across the Colombian and Ecuadorian Andes to Northern Peru, in an elevational range between 450 to 3.000 m.a.s.l. (Gómez-Laverde et al. 2016, Brito et al. 2017).

This species inhabits primary and secondary forests and cultivated areas, where it feeds on small fruits, vegetal material and occasionally insects (Linares 1998, Tirira 2007, Brito et al. 2017), thus, it plays an important role in forest regeneration because it disperses seeds through the transport, accumulation and fruit consumption (Montenegro-Díaz et al. 1991).

Although R. latimanus uses all forest strata, it prefers to live in the forest canopy, where it uses hollow trees, palm leaves or dense vegetation as diurnal roost (Brito et al. 2017). However, the information on the biology and ecology of this species is mostly unknown (Montenegro-Díaz et al. 1991, Tirira 2007), therefore, it is necessary to report new data about the knowledge of the species.

In this note, I report two field observations of $R$. latimanus using caves. I recorded the observations during diurnal internal caves surveys looking for bats in the municipality of Charalá (Santander, Colombia) in July 2001. The first observation was into an unnamed cave, at the El Mirador farm, vereda El Salitre $(6,2643,-73,115944)$ at 1.534 m.a.s.l., on July 11, 2001. The Cave has a long passage of approximately $400 \mathrm{~m}$ with nonbranching side tunnels (1,5 $\mathrm{m} \mathrm{x} 2 \mathrm{~m}$ ). A stream crossed the cave along the middle of the passage. When the team was crossing the cave, we saw more than 10 rats running next to us. A single adult female was captured using a hand-net. The specimen was preserved in alcohol and the skull was extracted, cleaned (field number MRP 016) and deposited in the mammal collection "Alberto Cadena García", Instituto de Ciencias Naturales, Universidad Nacional de Colombia, Bogotá, Colombia (ICN 17510). The specimen was identified as R. latimanus according to Tribe $(1996,2015)$. The other rats in the cave had similar external characters among the rats, I was able to distinguish a group of three rats, probably an adult female with two juveniles because they had a similar appearance but a different size. No other type of rat was observed in this cave.

\footnotetext{
Mammalogy Notes | Notas Mastozoológicas

Sociedad Colombiana de Mastozoología

Vol. 5 Núm. 2| 2019
} 
Another observation was in the El Salitre cave, in El Salitre Farm, vereda El Salitre $(6,262367,-73,125317)$ at 1375 m.a.s.l, on July 12, 2001. The cave has a long main passage of approximately $200 \mathrm{~m}$ with nonbranching side tunnels ( $2 \mathrm{~m} \times 4 \mathrm{~m}$ ). A stream crossed the cave along the middle of the passage. I found three roosting rats (Figure 1), all of them occupying a small deep hole between a cavity in the cave wall located at $70 \mathrm{~m}$ from the cave entrance. The interior of the hole was hard to see and practically inaccessible for me. A rat left the hole and ran on the cave walls for a few minutes and returned to the hole.

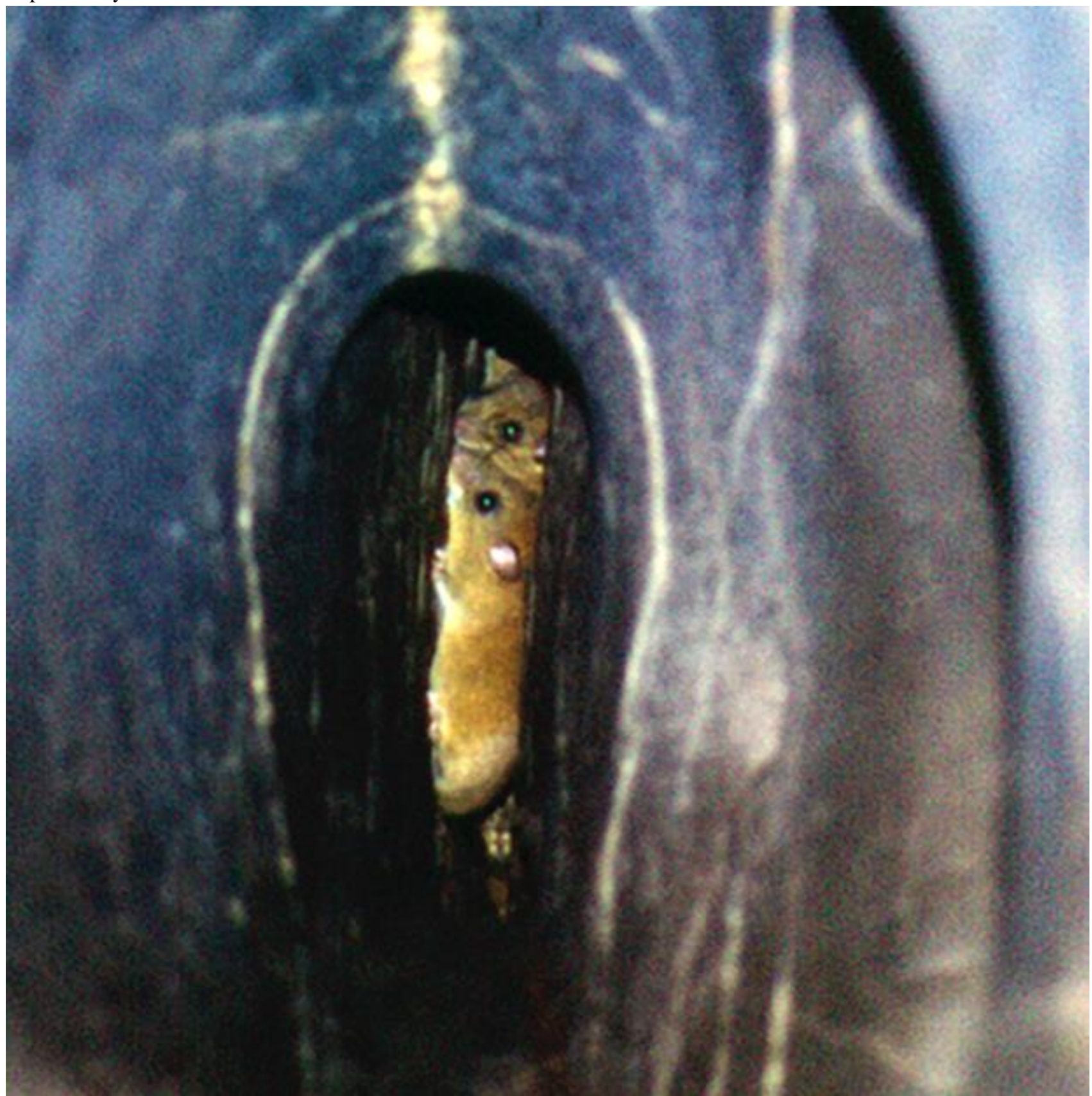

Figure 1. Three Broad-footed Climbing Rats (Rhipidomys latimanus) roosting in a small deep hole into the El Salitre cave (Charalá, Santander, Colombia). Photo MRP. 
These records provide new data about the natural history of $R$. latimanus, previously, this species was considered mainly arboreal and solitary, but the observations presented here suggest that these rats may roost in groups and use the cave as a roosting place or obtain other resources. To my knowledge, this is the first confirmed record of a rodent species using a cave in Colombia (see Muñoz-Saba et al. 1997, 1999, 2013). Finally, I want to draw attention to the need of increasing the knowledge about Colombian rodents, around 132 species have been registered in the country, with 75 species of them corresponding to mice and rats of the subfamily Sigmodontinae (Ramírez-Chaves et al. 2016), but we know very little about their natural history, including their biology, taxonomy, ecology, and distribution (Montenegro-Díaz et al. 1991).

\title{
Acknowledgements
}

The data reported here were taken during the field work of the student extension project "Caracterización de las comunidades de murciélagos asociados a 6 cavernas en los municipios de Charalá y Ocamonte (Santander, Colombia)". The welfare department of the Faculty of Sciences of the Universidad Nacional de Colombia financed part of the field trip. The ICN Mammal collection provided logistic and academic support, mainly Hugo López Arévalo and Alberto Cadena García. The "Instituto Colombiano Agropecuario-seccional San Gil" and the "Hogares Juveniles Campesinos" support transportation and lodging in the study area. The specimen was collected under a research license in accordance with Resolution No. 00000050 dated January 15, 2012 granted by “Corporación Autónoma Regional de Santander" (CAS). I thank Aida Otálora-Ardila and Angela Camargo-Sanabria who worked with me on the bat cave project.

\section{References}

Brito, J., Pardiñas, U. and D. Ruelas. 2017. Rhipidomys latimanus (Broad footed Climbing rat). Pp. 484 in Handbook of the mammals of the world. Vol 7. Rodents II (D. E. Wilson, D. T. E. Lacher Jr., and R. A. Mittermeier, eds.). Lynx Editions. Barcelona.

Eisenberg, J. F. 1989. Mammals of the neotropics. The northern Neotropics. The University of Chicago Press. Chicago.

Gómez-Laverde, M., Tirira, D. and C. Delgado. 2016. Rhipidomys latimanus (errata version published in 2017). The UICN Red List of Threatened Species 2016: e.T19609A115151910. https://dx.doi.org/10.2305/IUCN.UK.2016-3.RLTS.T19609A22374815.en (Downloaded on 14 March 2020).

Linares, O. J. 1998. Mamíferos de Venezuela. Editorial Sociedad Conservacionista Audubon de Venezuela. Caracas, Venezuela.

Montenegro-Díaz, O., López-Arévalo, H. and A. Cadena. 1991. Aspectos ecológicos del roedor arborícola Rhipidomys latimanus Tomes, 1860, (Rodentia: Cicetidae) en el Oriente de Cundinamarca, Colombia. Caldasia 16(79): 565-572.

Muñoz-Saba, Y., Andrade, G. I. and L.G. Baptiste. 1997. Cuevas y Cavernas. Pp. 164-175 in Informe Nacional sobre el estado de la biodiversidad biológica (Chaves-S., M.E., and N. Arango-V, eds.). Instituto Alexander von Humboldt, Ministerio del Medio Ambiente, Programa de las Naciones Unidas para el Medio Ambiente (PNUMA), Panamericana Formas e Impresos S.A. Bogotá.

Muñoz-Saba, Y., López, H. F. and A. Cadena. 1999. Aportes al conocimiento de la ecología de los murciélagos de los afloramientos de mármoles y calizas, sector de Río Claro (Antioquia, Colombia). Revista de la Academia Colombiana de Ciencias Exactas, Físicas y Naturales. 23: 651-658.

Muñoz-Saba Y., González-Sánchez, I. and N. Calvo-Roa. 2013. Cavernas de Santander, Colombia: Guía de campo. Serie de Guías de Campo del Instituto de Ciencias Naturales No 13. Instituto de Ciencias Naturales, Universidad Nacional de Colombia, Bogotá.

Ramírez-Chaves, H. E., Suárez-Castro, A. F. and J. F. Gonzáles-Maya. 2016. Cambios recientes a la lista de los mamíferos de Colombia. Mammalogy Notes 3(1):1-19.

Tirira, D. 2007. Guía de campo de los mamíferos del Ecuador. Publicación especial sobre los mamíferos del Ecuador. Ediciones Murciélago Blanco. Quito.

Tribe, C. J. 1996. The neotropical rodent genus Rhipidomys (Cricetidae: Sigmodontinae)-A taxonomic Revision. PhD thesis. University of London, London.

Tribe, C. J. 2015. Genus Rhipidomys Tschuddii, 1845. Pp 583-617 in Mammals of South America. Vol 2 Rodents (Patton J.L., Pardiñas, U. F. J. and G. D’Elía, eds.). The University of Chicago Press, Chicago, Illinois.

\author{
Mammalogy Notes | Notas Mastozoológicas \\ Sociedad Colombiana de Mastozoología \\ Vol. 5 Núm. 2| 2019
}

